\title{
APOE*E4 Is Associated with Gray Matter Loss in the Posterior Cingulate Cortex in Healthy Elderly Controls Subsequently Developing Subtle Cognitive Decline
}

\author{
(D) S. Haller, (DM.-L. Montandon, (D) Rodriguez, (D) M. Ackermann, (DF.R. Herrmann, and (DP. Giannakopoulos
} O- $\equiv$

\begin{abstract}
BACKGROUND AND PURPOSE: The presence of apolipoprotein E4 (APOE*E4) is the strongest currently known genetic risk factor for Alzheimer disease and is associated with brain gray matter loss, notably in areas involved in Alzheimer disease pathology. Our objective was to assess the effect of $A P O E^{\star} E 4$ on brain structures in healthy elderly controls who subsequently developed subtle cognitive decline.
\end{abstract}

MATERIALS AND METHODS: This prospective study included 382 community-dwelling elderly controls. At baseline, participants underwent MR imaging at 3T, extensive neuropsychological testing, and genotyping. After neuropsychological follow-up at 18 months, participants were classified into cognitively stable controls and cognitively deteriorating controls. Data analysis included whole-brain voxelbased morphometry and ROI analysis of GM.

RESULTS: $A P O E^{\star} E 4$-related GM loss at baseline was found only in the cognitively deteriorating controls in the posterior cingulate cortex. There was no $A P O E^{\star} E 4$-related effect in the hippocampus, mesial temporal lobe, or brain areas not involved in Alzheimer disease pathology. Controls in the cognitively deteriorating group had slightly lower GM concentration in the hippocampus at baseline. Higher GM densities in the hippocampus, middle temporal lobe, and amygdala were associated with a decreased risk for cognitively deteriorating group status at follow-up.

CONCLUSIONS: $A P O E^{\star} E 4$-related GM loss in the posterior cingulate cortex (an area involved in Alzheimer disease pathology) was found only in those elderly controls who subsequently developed subtle cognitive decline but not in cognitively stable controls. This finding might explain the partially conflicting results of previous studies that typically did not include detailed neuropsychological assessment and follow-up. Most important, $A P O E^{\star} E 4$ status had no impact on GM density in areas affected early by neurofibrillary tangle formation such as the hippocampus and mesial temporal lobe.

ABBREVIATIONS: $\mathrm{AD}=$ Alzheimer disease; $\mathrm{APOE}=$ apolipoprotein $\mathrm{E} ; \mathrm{dCON}=$ cognitively deteriorating controls; $\mathrm{MCI}=$ mild cognitive impairment; $\mathrm{sCON}=$ cognitively stable controls

$\mathbf{T}$ he apolipoprotein $E$ gene $(A P O E)$ has 3 different alleles, $A P O E^{\star} E 2, A P O E^{\star} E 3$, and $A P O E^{\star} E 4$. The presence of $A P O E^{\star} E 4$ is the strongest currently known genetic risk factor for Alzheimer disease (AD). ${ }^{1,2} A P O E^{\star} E 3$ is the most common variant in the general population, while the $A P O E^{\star} E 2$ variant is associated with a lower risk of $\mathrm{AD}$. The $A P O E$ variant modifies not only the risk of $\mathrm{AD}$ but also the age of onset of cognitive symptoms. ${ }^{3,4}$

Received September 25, 2016; accepted after revision February 17, 2017

From the Affidea Centre de Diagnostic Radiologique de Carouge (S.H.), Geneva, Switzerland; Faculty of Medicine (S.H., M.-L.M., F.R.H., P.G.), University of Geneva, Switzerland; Departments of Surgical Sciences and Radiology (S.H.), Uppsala University, Uppsala, Sweden; Department of Neuroradiology (S.H.), University Hospital Freiburg, Freiburg, Germany; and Department of Mental Health and Psychiatry (M.-L.M., M.A.), Division of Institutional Measures, Medical Direction (C.R., P.G.), and Division of Geriatrics, Department of Internal Medicine, Rehabilitation and Geriatrics (F.R.H.), University Hospitals of Geneva, Geneva, Switzerland.

This work is supported by Swiss National Foundation grants SNF 3200B0-1161193 and SPUM 33CM30-124111 and an unrestricted grant from the Assocation Suisse pour la Recherche Alzheimer.
Cross-sectional structural MR imaging studies indicated reduced gray matter in elderly $A P O E^{\star} E 4$ carriers including healthy controls, subjective memory impairment, mild cognitive impairment (MCI), and AD. ${ }^{5-14}$ In $\mathrm{MCI}$ and $\mathrm{AD}$, the $A P O E^{\star} E 4$-related GM decrease seems to affect areas involved in AD pathology, notably the hippocampus, amygdala, and mesial temporal cortex ${ }^{14-17}$ but also the left occipital, frontal, and anterior cingulate cortices. ${ }^{14,18}$ In healthy elderly controls, the $A P O E^{\star} E 4$ effect on brain structure is less clear. Decreased GM volume in the caudate nuclei ${ }^{14}$ and the right cingulate gyrus and decreased white matter

Please address correspondence to Sven Haller, MD, MSc, Affidea Centre de Diagnostic Radiologique de Carouge CDRC, Geneva, Switzerland; Faculty of Medicine of the University of Geneva, Geneva, Switzerland; Departments of Surgical Science and Radiology, Uppsala University, Uppsala, Sweden; Department of Neuroradiology, University Hospital Freiburg, Freiburg, Germany; e-mail: sven.haller@me.com

-- Indicates open access to non-subscribers at www.ajnr.org

三 Indicates article with supplemental on-line table.

http://dx.doi.org/10.3174/ajnr.A5184 
integrity in right parahippocampal gyrus ${ }^{19}$ were found. However, negative data were also reported. ${ }^{15,18,20}$ In younger $A P O E^{\star} E 4$ carriers, the results are also more ambiguous. Some studies demonstrated reduced GM in middle-aged ${ }^{21}$ and young $A P O E^{\star} E 4$ carriers $^{22,23}$ compared with the other $A P O E$ allele carriers, whereas others reported no $A P O E^{\star} E 4$ effect throughout adulthood. ${ }^{20}$

Longitudinal studies also indicated that among MCI converters, those with a positive $A P O E^{\star} E 4$ status displayed increased GM atrophy in $\mathrm{AD}$-related brain regions. ${ }^{24,25}$

The current investigation goes 1 step earlier in the degenerative process and assesses the effect of $A P O E$ allele status in healthy controls who subsequently developed subtle cognitive decline. To this end, we performed MR imaging and cognitive assessment at baseline in 382 community-dwelling elderly controls. Extensive cognitive assessment was repeated at 18 -month follow-up to define a subsample of 181 individuals with a stable condition and 201 with a deteriorating condition. We demonstrated a gradually progressive GM loss in the posterior cingulate cortex as a function of $A P O E$ alleles $(E 2<E 3<E 4)$ only in deteriorating groups, with preserved GM densities in cognitively stable groups.

\section{MATERIALS AND METHODS}

\section{Study Protocol and Participants}

All data used in the preparation of this article were obtained from a large, population-based study of community-dwelling older adults who have undergone an 18-month follow-up. These community-dwelling subjects were recruited via advertisements in local newspapers and media. All participants had normal or corrected-to-normal visual acuity, and none reported a history of neurologic or psychiatric disorders or alcohol or drug abuse. To avoid contamination by reversible forms of cognitive decline, subjects with vitamin B12 or folic acid deficiency and those with infectious diseases were excluded. Subjects with regular use of neuroleptics, antidepressants, mood stabilizers, anticonvulsant drugs, or psychostimulants and those with contraindications to MR imaging were excluded. Initially, 433 patients were screened. Thirty-seven refused to continue after the first evaluation (no death or illness, but for personal reasons). Fourteen were not considered due to the above-mentioned exclusion criteria. Five among them had substantial abnormal findings on MR imaging at baseline.

The education level was defined according to the Swiss scholar system, in which level $1=<9$ years (primary school), level $2=$ between 9 and 12 years (high school), and level $3=>12$ years (university). All participants provided written informed consent after formal approval by the local ethics committee.

\section{Neuropsychological Assessment}

At baseline, all individuals were evaluated with an extensive neuropsychological battery, including the Mini-Mental State Examination, ${ }^{26}$ the Hospital Anxiety and Depression Scale, ${ }^{27}$ and the Lawton Instrumental Activities of Daily Living. ${ }^{28}$ Cognitive assessment included the following: 1) attention (Digit-Symbol-Coding, ${ }^{29}$ Trail-Making Test $\mathrm{A},{ }^{30}$ ); 2) working memory (verbal: Digit Span Forward $^{31}$; visuospatial: visual memory span $\left[\right.$ Corsi ${ }^{32}$ ); 3) episodic memory (verbal: RI-48 Cued Recall Test ${ }^{33}$; visual: Shapes Test $^{34}$ ); 4) executive functions (Trail-Making Test $\mathrm{B},{ }^{30}$ Wisconsin
Card Sorting Test, and Phonemic Verbal Fluency Test); 5) language (Boston Naming Test ${ }^{35}$ ); 6) visual gnosis (Ghent Overlapping Figures); and 7) apraxia: ideomotor, ${ }^{36}$ reflexive, ${ }^{37}$ and constructional (Consortium to Establish a Registry for Alzheimer Disease; figure copy test ${ }^{38}$ ). All individuals were also evaluated with the Clinical Dementia Rating scale. ${ }^{39}$

Those who met dementia the Diagnostic and Statistical Manual of Mental Disorders, 4th edition, diagnostic criteria based on the neuropsychological and clinical assessments were excluded. In agreement with the criteria of Petersen et al, ${ }^{40}$ participants with a Clinical Dementia Rating scale score of 0.5 but no dementia and a score of $>1.5$ SDs below the age-appropriate mean in any of the previously mentioned tests were also excluded from the present study. Participants with neither dementia nor MCI were classified as cognitively healthy older controls and underwent full neuropsychological assessment at follow-up by the same neuropsychologist, on average 18 months later. Those whose cognitive scores remained stable and those whose performance at follow-up was at least $0.5 \mathrm{SD}$ lower compared with the baseline evaluation in at least 2 cognitive tests were classified as stable ( $\mathrm{sCON}$ ) and deteriorating (dCON), respectively. Two neuropsychologists clinically assessed all individuals independently. The final classification of sCON versus dCON was made by a trained neuropsychologist who took into account both the neuropsychological test results and overall clinical assessment. ${ }^{41}$ In her final appreciation, the trained neuropsychologist considered the most relevant test performances, usually altered in the course of Alzheimer disease (verbal episodic memory: RI-48 Cued Recall Test; attention: TrailMaking Test A; executive functions: Trail-Making Test $\mathrm{B}^{30}$ and Phonemic Verbal Fluency Test). Among the 2 tests needed for dCON classification, altered cognitive scores in at least 1 of these tests were mandatory.

\section{MR Imaging Acquisition}

Imaging data were acquired on a clinical routine whole-body $3 \mathrm{~T}$ MR scanner (Tim Trio; Siemens, Erlangen, Germany). The structural 3D T1 sequence was performed with the following fundamental parameters: $256 \times 256$ matrix; 176 sections; $1 \times 1 \times 1$ $\mathrm{mm}^{3}$; TE, $2.3 \mathrm{~ms}$; TR, $2300 \mathrm{~ms}$. Additional sequences (T2WI, susceptibility-weighted imaging, diffusion tensor imaging) were used to exclude incidental brain lesions.

\section{Genetic Testing}

Whole-blood samples were collected at baseline for all subjects for APOE genotyping. Standard DNA extraction was performed by using either 9-mL ethylenediaminetetraacetic acid tubes (Sarstedt AG, Nümbrecht, Germany) or the Oragene Saliva DNA Kit (DNA Genotek; Kanata, Ontario, Canada); tubes were stored at $-20^{\circ} \mathrm{C}$. APOE genotyping was performed on the LightCycler (Roche Diagnostics, Basel, Switzerland) as described previously. ${ }^{42}$

\section{Statistical Analysis}

The voxel-based morphometry analysis was performed by using the FSL software package (http://www.fmrib.ox.ac.uk/fsl/), according to the standard procedure. The essential processing steps included brain extraction with the FSL Brain Extraction Tool (http://fsl.fmrib.ox.ac.uk/fsl/fslwiki/BET), tissue-type segmenta- 
Table 1: Essential demographic data of the included study groups of stable and deteriorating elderly control participants ${ }^{\mathrm{a}}$

\begin{tabular}{|c|c|c|c|c|c|c|c|c|c|c|c|}
\hline \multirow[b]{2}{*}{ Group } & \multicolumn{3}{|c|}{ sCON Alleles } & \multicolumn{3}{|c|}{ dCON Alleles } & \multirow{2}{*}{$\begin{array}{l}\text { APOE Allele Effect } \\
3 / 3 \text { vs } 3 / 2 \text { ( } P \text { Value) }\end{array}$} & \multirow{2}{*}{$\begin{array}{l}\text { APOE Allele Effect } \\
4 / 3 \text { vs } 3 / 2 \text { ( } P \text { Value) }\end{array}$} & \multirow{2}{*}{$\begin{array}{c}\text { Group Effect } \\
\text { ( } P \text { Value) }\end{array}$} & \multirow{2}{*}{$\begin{array}{c}\text { Interaction } 1 \\
(P \text { Value })\end{array}$} & \multirow{2}{*}{$\begin{array}{c}\text { Interaction } 2 \\
(P \text { Value })\end{array}$} \\
\hline & $3 / 2$ & $3 / 3$ & $4 / 3$ & $3 / 2$ & $3 / 3$ & $4 / 3$ & & & & & \\
\hline No. & 22 & 132 & 27 & 21 & 142 & 38 & & & & & \\
\hline Sex & & & & & & & .734 & .411 & .172 & .261 & .359 \\
\hline Female & 13 & 83 & 19 & 8 & 86 & 26 & & & & & \\
\hline Male & 9 & 49 & 8 & 13 & 56 & 12 & & & & & \\
\hline Education (yr) & & & & & & & .466 & .324 & .676 & .808 & .450 \\
\hline$<9$ & 3 & 23 & 4 & 3 & 27 & 3 & & & & & \\
\hline $9-12$ & 8 & 53 & 14 & 9 & 72 & 20 & & & & & \\
\hline$>12$ & 11 & 56 & 9 & 9 & 43 & 15 & & & & & \\
\hline Age (yr) & & & & & & & .980 & .969 & .377 & .952 & .539 \\
\hline Mean & 73.7 & 73.7 & 73.8 & 74.8 & 74.9 & 73.9 & & & & & \\
\hline SD & 3.2 & 3.9 & 4.2 & 4.4 & 4.2 & 4.0 & & & & & \\
\hline
\end{tabular}

a Data in columns 2-7 are number.

tion with the FMRIB Automated Segmentation Tool (http:// fsl.fmrib.ox.ac.uk/fsl/fslwiki/fast), nonlinear transformation into Montreal Neurological Institute reference space, and creation of a study-specific GM template to which the native GM images were then nonlinearly reregistered. The modulated segmented images were then smoothed with an isotropic Gaussian kernel with a $\sigma$ of $2 \mathrm{~mm}$. Finally, the voxelwise FSL General Linear Model (http:// fsl.fmrib.ox.ac.uk/fsl/fslwiki/GLM) was applied by using permutation-based nonparametric testing with the FSL Randomize tool (http://fsl.fmrib.ox.ac.uk/fsl/fslwiki/Randomise/) with thresholdfree cluster enhancement correction for multiple comparisons, ${ }^{43}$ considering fully corrected $P$ values $<.05$ as significant. The analysis was performed to compare regions and $A P O E$ genotypes with the percentage of GM as a dependent variable with age, sex, and education as potential confounders. Furthermore, we created a mask for the bilateral mesial temporal cortex, posterior cingulate cortex, hippocampus, amygdala, caudate nuclei, and parietal and occipital lobes that was then applied to the GM image of the study-specific template.

Demographic and neuropsychological data were compared among groups by using regression models with group (stable versus deteriorating), APOE genotype (3/2,3/3,4/3), and a group $\times$ genotype interaction term as predictors. Logistic, ordered logistic, and linear regression models were used for binary, ordinal, and respectively continuous variables. Group effects (stable versus deteriorating) were compared by using the $Z$-test for plain and ordered logistic regressions and the $t$ test for linear regression.

Logistic regression models were built to assess the relationship between cognitive status (dependent variable) and APOE genotyping, GM densities in the 3 areas of interest (posterior cingulate, hippocampus, mesial temporal lobe), age, sex, and education levels (independent variables). Because GM density values were all ranging between 0.32 and 0.87 , we transformed them by using $z$ scores (subtracting the overall mean and dividing by the overall SD) and thus calculated the standardized odds ratio, which represents the decrease in estimated risk for a 1-SD change in GM density.

\section{RESULTS}

\section{Demographic and Neuropsychological Data}

The final sample included 382 subjects with 3D T1 scans available and $A P O E$ genotyping. We grouped these subjects into 3 groups: 43 with $A P O E^{\star} E 2$ (mean age, $74.1 \pm 3.8$ years; 22 with sCON and
21 with dCON), 274 with $A P O E^{\star} E 3$ (mean age, $74.1 \pm 4.1$ years; 132 with sCON and 142 with dCON), and 65 with $A P O E^{*} E 4$ (mean age, $73.6 \pm 4.1$ years; 27 with sCON and 38 with dCON) genotypes. Demographic data and neuropsychological performances at baseline did not differ between sCON and dCON groups (data not shown). As expected, there were group differences at follow-up, with worse cognitive performances of dCON for the Trail-Making Test B $(P=.015)$, Verbal Fluency ( $P=$ .045 ), and the Wisconsin Card Sorting Test (number of categories) $(P=.034)$. The $A P O E^{\star} E 4$ allele had a negative impact on verbal fluency performance at follow-up $(P=.011)$ with a significant group $\times A P O E$ interaction $(P=.003$ for $\mathrm{dCON})$. There was no other significant association between $A P O E$ genotyping and neuropsychological performances at follow-up (Table 1 and Online Table).

\section{Whole-Brain Voxel-Based Morphometry}

In a first step, we performed a voxelwise analysis across the entire brain. The posterior cingulate cortex demonstrated a significant difference between $A P O E^{\star} E 3>A P O E^{\star} E 4$ for the dCON group (Fig 1).

\section{ROI Analysis: APOE Effect on GM Densities in dCON and SCON}

In a second step, we additionally performed an ROI analysis in 7 regions of particular interest in the context of cognitive decline (posterior cingulate cortex, hippocampus, mesial temporal lobe, parietal lobe, amygdala, and caudate nucleus) with the occipital lobe as a control region.

In the posterior cingulate, the GM concentration decreased from $E 2$ to $E 3$ to $E 4$ across all participants. When we separated the patients into stable-versus-deteriorating controls, this decrease in GM concentration was present in only the dCON group (Fig $2 \mathrm{~A}$ and Table 2). Moreover, we found a significant difference between sCON versus dCON in $A P O E^{\star} E 4$-positive individuals. Concerning the hippocampus, patients with $\mathrm{dCON}$ had lower GM concentrations compared with those with sCON, which was significant only in the $A P O E^{\star} E 3$ group, presumably due to the large sample size (Fig $2 B$ and Table 3 ). In the amygdala, there was a decrease in GM concentration from $A P O E^{\star} E 2$ to $A P O E^{\star} E 3$ to $A P O E^{\star} E 4$ in all participants, and this effect was present only in the sCON but not in the dCON subgroups (Fig 2C and Table 3). In the parietal lobe, the pattern was inverse, with increased GM con- 


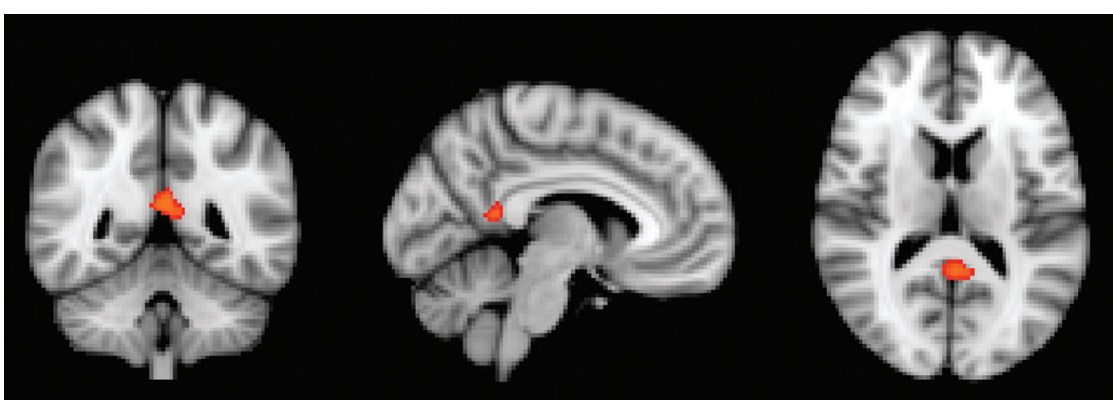

FIG 1. Whole-brain voxel-based morphometry analysis demonstrating higher GM density for the comparison of $A P O E^{\star} E 3>A P O E^{\star} E 4$ in the posterior cingulate cortex. $P<.05$ corrected.

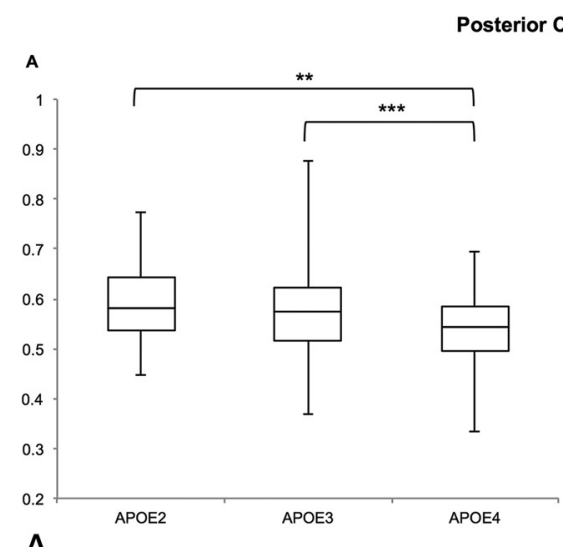

Posterior Cingulate Cortex

A
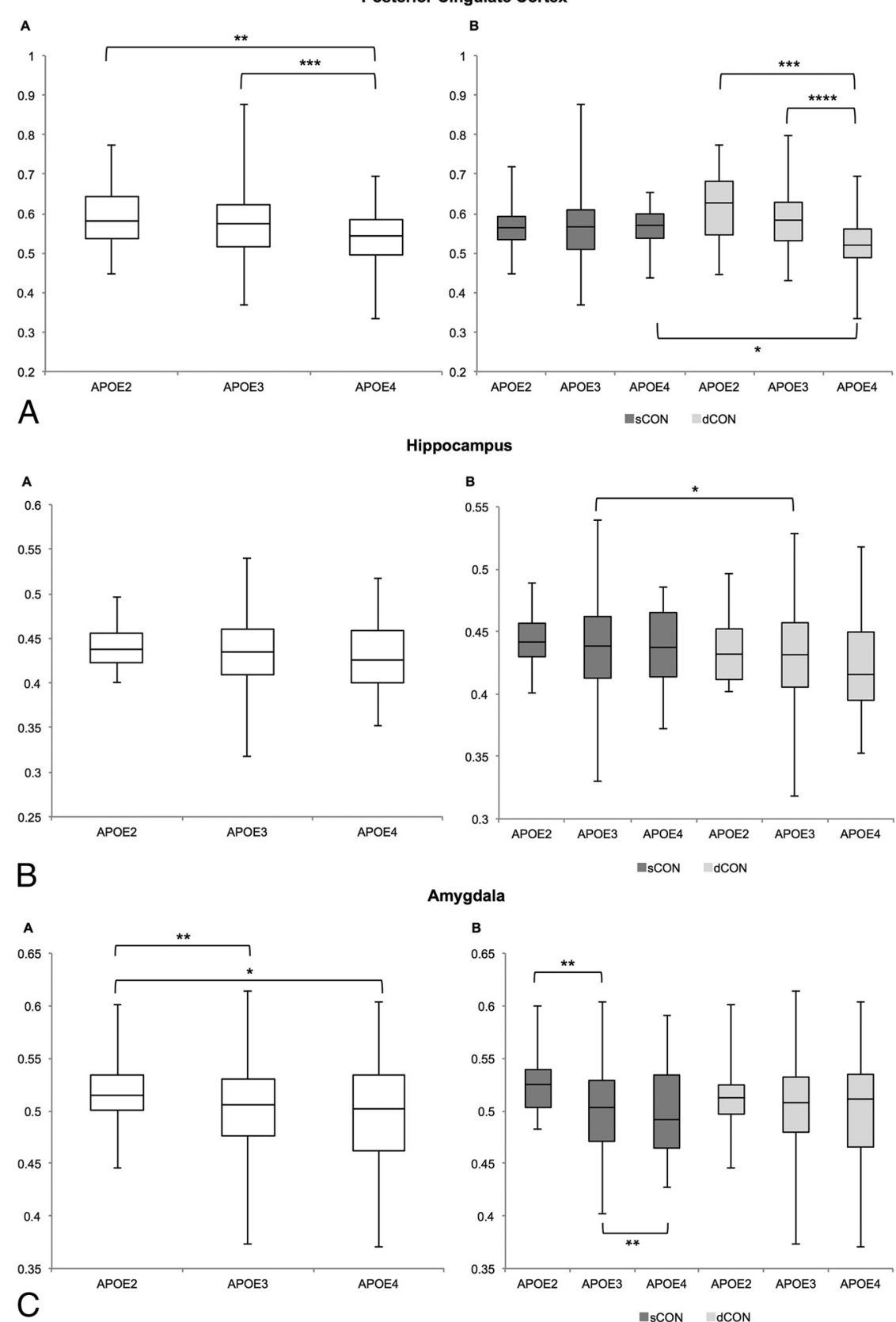

Hippocampus
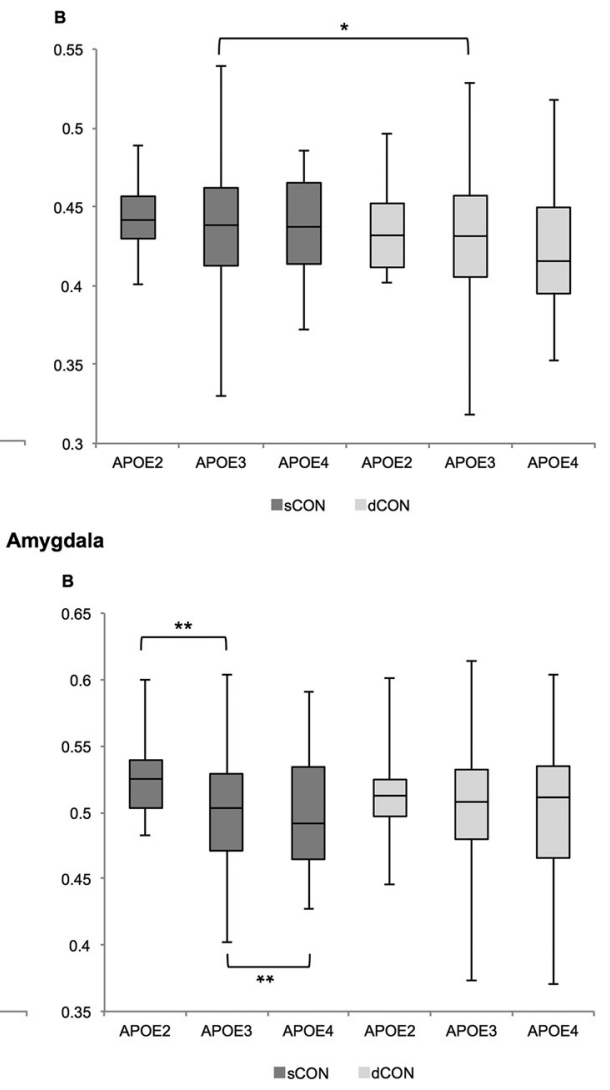

FIG 2. ROI analysis of GM density depending on APOE status for the 7 target regions for all elderly controls (left-hand side) and separately for subjects with sCON and dCON (right-hand side). One asterisk indicates $P<.05 ; 2$ asterisks, $P<.01 ; 3$ asterisks, $P<.001 ; 4$ asterisks, $P<.0001$. centration in those with dCON, notably in those with $A P O E^{\star} E 3$ and $A P O E^{\star} E 4$ (Fig $2 D$ and Table 3 ). No significant differences were found in the mesial temporal lobe, occipital lobe, or caudate nuclei (Fig 2E-G and Table 3).

\section{Logistic Regression Models}

Higher GM densities in the hippocampus, middle temporal lobe, and amygdala were all associated with a decreased risk for dCON status at follow-up (hippocampus: standardized OR $=0.75 ; 95 \% \mathrm{CI}$, 0.61-0.92; $P=.006$; middle temporal lobe: standardized OR $=0.80 ; 95 \% \mathrm{CI}$, 0.65-0.98; $P=.028$; and amygdale: standardized OR $=0.75 ; 95 \%$ CI, 0.610.93, $P=.008$ ). Although significant, these associations explained $<1.5 \%$ of cognitive variability. APOE genotyping, age, sex, and duration did not predict dCON status at follow-up. When categorizing GM densities into quintiles, we confirmed the assumption of a linearity of their association with the log odds, because the odds ratios displayed a gradient that is statistically significant for quintile 4 (threshold $\geq 0.4426118$ ) and quintile 5 (threshold $\geq 0.48496512$ ), with ORs of $0.51(P=.044)$ and 0.44 $(P=.013)$.

\section{DISCUSSION}

Several studies demonstrated that the presence of the $A P O E^{\star} E 4$ allele modulates the expression of brain atrophy in MCI and clinically overt AD, increasing the vulnerability of the areas prone to early neurodegeneration such as the hippocampus, amygdala, and mesial temporal lobe. ${ }^{15-17}$ Although higher cortical amyloid $\beta$ load and decreased metabolism in the above-mentioned areas were reported in the $A P O E^{*} E 4$ allele, crosssectional MR imaging studies failed to identify consistent GM decreases associated with this genotype in elderly controls (for a review see Fouquet et $\mathrm{al}^{44}$ ). The finding in the current investigation that $A P O E^{\star} E 4$ was related to GM loss in only the subsequently deteriorating but not in the cognitively stable groups might explain these partially conflicting results of previous studies, which typically do not include detailed neuropsychological assessment and follow-up.

The present data show that the $A P O E^{\star} E 4$ genotype is not associated 


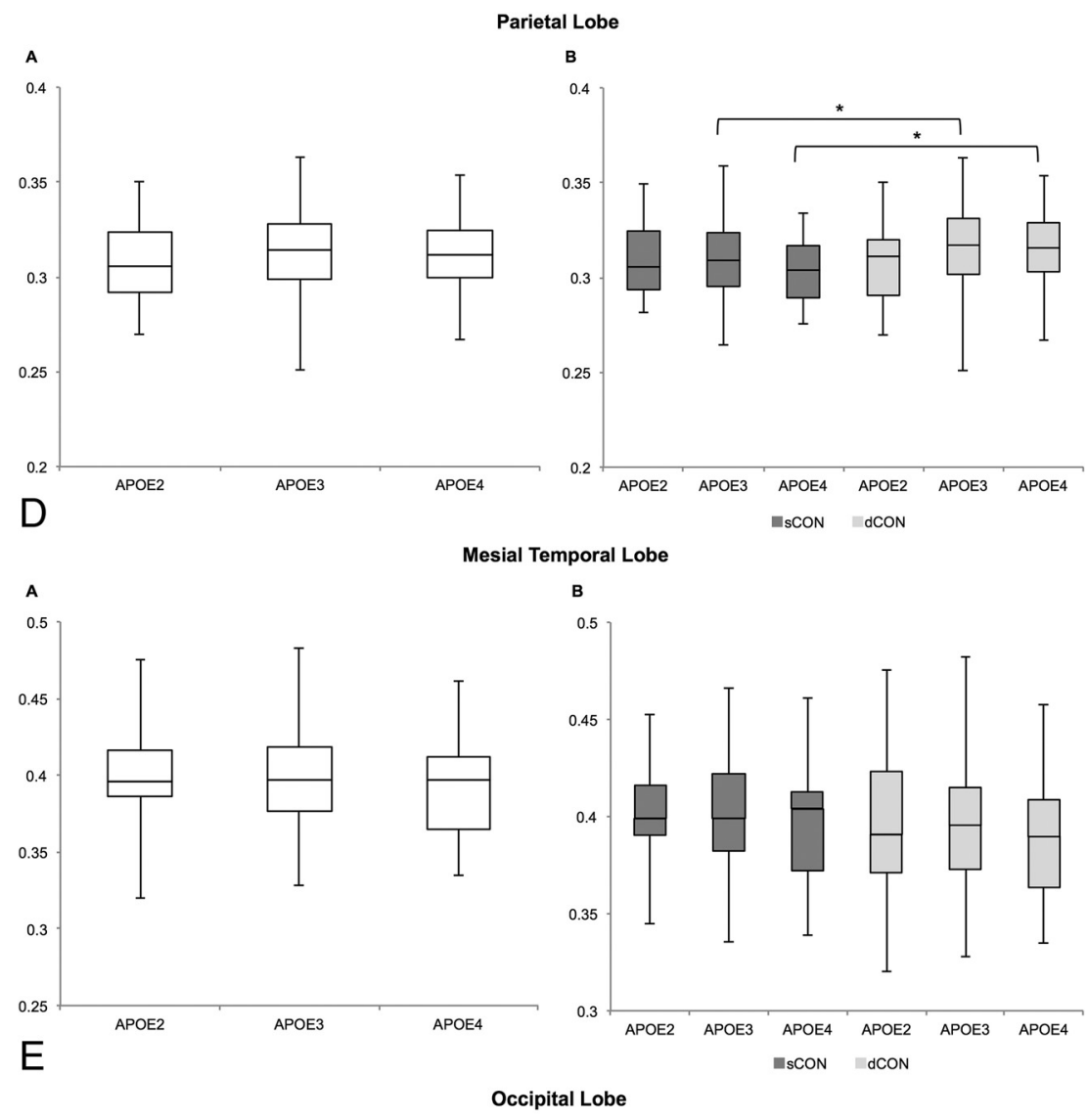

sial temporal cortex in subjects with both sCON and dCON. In agreement with previous observations in this field, these observations indicate that the $A P O E^{*} E 4$ allele detrimental effect in terms of structural changes and clinical progression becomes evident only in elderly individuals with significant cognitive deterioration (MCI) or clinically overt symptoms of dementia (early AD). ${ }^{14-17}$

The posterior cingulate cortex is known to be affected early in the $\mathrm{AD}$ process with significant hypometabolism in cognitively healthy individuals and those with MCI (both converters and nonconverters; for review see Teipel and Grothe ${ }^{45}$ ). In more advanced stages of the degenerative process, this area exhibits subtle atrophy and hypometabolism in subjects with amnestic amyloid-negative $\mathrm{AD} .{ }^{46}$ Rare cross-sectional studies addressed the impact of $A P O E$ genotyping on the structural and functional integrity of the posterior cingulate cortex. Early contributions from the Cardiovascular Health Study indicated an $A P O E^{*} E 4$-independent age-related atrophy in the hippocampus and posterior cingulate cortex in healthy elderly controls. ${ }^{47}$ More recently, an altered energy metabolism was reported in this area in young adult $A P O E^{*} E 4$ carriers. ${ }^{48}$ In the same line, Lu et al ${ }^{49}$ reported cortical atrophy in the right cingulate gyrus in cognitively intact $A P O E^{\star} E 4$ carriers. Our observations parallel these findings, suggesting that the presence of this allele may have a detrimental effect on GM density in this vulnerable area.

The strengths of the present study include its longitudinal design, large number of community-dwelling subjects, and detailed neuropsychological testing at inclusion and follow-up. However, some limitations should also be considered. First, in line with recent core clinical criteria for $\mathrm{MCI},{ }^{50}$ the identification of deteriorating controls was based on the objective decline in cognitive functions measured by using serial, comprehensive neuropsychological assessments. However, in the absence of longer follow-up and $\mathrm{AD}$ biomarker characterization at baseline (including PET amyloid scans or the CSF $\tau$ /amyloid

FIG 2. Continued.

with an increased risk of dCON status at follow-up. Consistent with previous reports in elderly controls, ${ }^{15,18,20}$ no APOE genotyping-related effect was identified in the hippocampus and me- $\beta 42$ ratio), the cognitive fate of these individuals remains uncertain so that they cannot be a priori considered as subjects with incipient $\mathrm{AD}$. Second, the rarity of $A P O E^{\star} E 4$ homozygotes pre- 
Table 2: ROI analysis of GM concentration in the 7 regions for the comparison of sCON versus dCON ${ }^{\mathrm{a}}$

\begin{tabular}{lccccccc}
\hline & \multicolumn{7}{c}{ sCON versus dCON } \\
\cline { 2 - 7 } & $\begin{array}{c}\text { Posterior } \\
\text { Cingulate }\end{array}$ & Hippocampus & $\begin{array}{c}\text { Mesial Temporal } \\
\text { Cortex }\end{array}$ & $\begin{array}{c}\text { Parietal } \\
\text { Lobe }\end{array}$ & $\begin{array}{c}\text { Occipital } \\
\text { Lobe }\end{array}$ & $\begin{array}{c}\text { Caudate } \\
\text { Amygdala }\end{array}$ & Nuclei \\
\hline APOE $^{\star} E 2(n=22 / 21)$ & .0524 & .3890 & .4189 & .8146 & .4223 & .3146 & .2863 \\
APOE $^{\star} E 3(n=132 / 142)$ & .0813 & $.0261^{\mathrm{b}}$ & .0756 & $.0349^{\mathrm{b}}$ & .2425 & .2567 & .1384 \\
APOE $^{\star} E 4(n=27 / 38)$ & $.0155^{\mathrm{b}}$ & .1916 & .4076 & $.0316^{\mathrm{b}}$ & .2433 & .5410 & .3960 \\
\hline
\end{tabular}

${ }^{a}$ Data are $P$ values.

${ }^{\mathrm{b}} P<.05$.

Table 3: ROI analysis of GM concentration in the 7 regions for the comparison of $A P O E^{\star} E 2$ versus $A P O E^{\star} E 3$ and $A P O E^{\star} E 2$ versus $A P O E^{\star} E 4$ and $A P O E^{\star} E 3$ versus $A P O E^{\star} E 4$

\begin{tabular}{|c|c|c|c|}
\hline & $\begin{array}{c}A^{A P O E^{\star} E 2} \text { versus } \\
A P O E^{\star} E 3\end{array}$ & $\begin{array}{c}A P O E^{\star} E 2 \text { versus } \\
A P O E^{\star} E 4\end{array}$ & $\begin{array}{c}A P O E^{\star} E 3 \text { versus } \\
A P O E^{\star} E 4\end{array}$ \\
\hline \multicolumn{4}{|c|}{ Posterior cingulate } \\
\hline $\mathrm{sCON}$ & $.7816(n=22 / 132)$ & $.9153(n=22 / 27)$ & $.6539(n=132 / 27)$ \\
\hline $\mathrm{dCON}$ & $.1989(n=21 / 142)$ & $.0004^{\mathrm{a}}(n=22 / 38)$ & $.00002^{\mathrm{b}}(n=132 / 38)$ \\
\hline \multicolumn{4}{|c|}{ Hippocampus } \\
\hline sCON & $P=.4227$ & $P=.3954$ & $P=.7191$ \\
\hline $\mathrm{dCON}$ & $P=.2852$ & $P=.1937$ & $P=.5711$ \\
\hline \multicolumn{4}{|c|}{ Mesial temporal lobe } \\
\hline sCON & $P=.7285$ & $P=.313$ & $P=.3601$ \\
\hline $\mathrm{dCON}$ & $P=.9713$ & $P=.5361$ & $P=.3119$ \\
\hline \multicolumn{4}{|c|}{ Parietal lobe } \\
\hline sCON & $P=.6977$ & $P=.4708$ & $P=.1469$ \\
\hline $\mathrm{dCON}$ & $P=.1433$ & $P=.2133$ & $P=.8734$ \\
\hline \multicolumn{4}{|c|}{ Occipital lobe } \\
\hline sCON & $P=.0596$ & $P=.6834$ & $P=.1617$ \\
\hline $\mathrm{dCON}$ & $P=.9744$ & $P=.6773$ & $P=.4631$ \\
\hline \multicolumn{4}{|l|}{ Amygdala } \\
\hline sCON & $P=.0025^{c}$ & $P=.0083^{c}$ & $P=.6342$ \\
\hline $\mathrm{dCON}$ & $P=.4174$ & $P=.3411$ & $P=.6874$ \\
\hline \multicolumn{4}{|c|}{ Caudate nuclei } \\
\hline sCON & $P=.2931$ & $P=.4369$ & $P=.8506$ \\
\hline $\mathrm{dCON}$ & $P=.9051$ & $P=.9427$ & $P=.9431$ \\
\hline
\end{tabular}

a $p<.001$.

${ }^{\mathrm{b}} P<.0001$.

${ }^{c} p<.01$.

cluded a detailed analysis of gene-dose effect on GM densities. Third, handedness was not considered as a covariate in our MR imaging analysis, which included both left- and right-handed controls.

\section{CONCLUSIONS}

Our data reveal that the presence of the $A P O E^{\star} E 4$ allele is associated with decreased GM density in the posterior cingulate cortex in dCON, a community-based group of elderly controls who subsequently had subtle cognitive decline at 18-month follow-up. This $A P O E$ effect was not identified in cognitively stable controls. Most important, the $A P O E^{\star} E 4$ allele has no impact on GM density in areas affected early by neurofibrillary tangle formation such as the hippocampus and mesial temporal lobe. These observations suggest that decreased GM density in the posterior cingulate cortex should be systematically detected among $A P O E^{\star} E 4$ controls because it could represent a structural marker preceding subtle cognitive deficits in the very early stages of the degenerative process.

Disclosures: Sven Haller-RELATED: Grant: Swiss National Foundation, Comments: grant SNF 3200B0-1161193 and SPUM 33CM30-124111* and an unrestricted grant from the Assocation Suisse pour la Recherche Alzheimer*. *Money paid to the institution.

\section{REFERENCES}

1. Corder EH, Saunders AM, Strittmatter WJ, et al. Gene dose of apolipoprotein E type 4 allele and the risk of Alzheimer's disease in late onset families. Science 1993;261:921-23 CrossRef Medline

2. Strittmatter WJ, Saunders AM, Schmechel D, et al. Apolipoprotein E: high-avidity binding to beta-amyloid and increased frequency of type 4 allele in late-onset familial Alzheimer disease. Proc Natl Acad Sci U S A 1993;90:1977-81 CrossRef Medline

3. Jack CR Jr, Therneau TM, Wiste HJ, et al. Transition rates between amyloid and neurodegeneration biomarker states and to dementia: a population-based, longitudinal cohort study. Lancet Neurol 2016; 15:56-64 CrossRef Medline

4. Jack CR Jr, Wiste HJ, Weigand SD, et al. Age-specific population frequencies of cerebral $\boldsymbol{\beta}$-amyloidosis and neurodegeneration among people with normal cognitive function aged 50-89 years: a cross-sectional study. Lancet Neurol 2014;13:997-1005 CrossRef Medline

5. Lee YM, Ha JK, Park JM, et al. Impact of apolipoprotein E4 polymorphism on the gray matter volume and the white matter integrity in subjective memory impairment without white matter hyperintensities: voxel-based morphometry and Tract-Based Spatial Statistics Study under 3-Tesla MRI. J Neuroimaging 2016;26: 144-49 CrossRef Medline

6. Li B, Shi J, Gutman BA, et al. Influence of APOE genotype on hippocampal atrophy over time: an $\mathrm{N}=1925$ surface-based ADNI study. PLoS One 2016;11:e0152901 CrossRef Medline

7. Shi J, Leporé N, Gutman BA, et al. Genetic influence of apolipopro- 
tein $\mathrm{E} 4$ genotype on hippocampal morphometry: an $\mathrm{N}=725$ surface-based Alzheimer's disease neuroimaging initiative study. Hum Brain Mapp 2014;35:-3903-18 CrossRef Medline

8. Goñi J, Cervantes S, Arrondo G, et al. Selective brain gray matter atrophy associated with APOE $\varepsilon 4$ and MAPT $\mathrm{H} 1$ in subjects with mild cognitive impairment. J Alzheimers Dis 2013;33:1009-19 CrossRef Medline

9. Lu PH, Thompson PM, Leow A, et al. Apolipoprotein E genotype is associated with temporal and hippocampal atrophy rates in healthy elderly adults: a tensor-based morphometry study. J Alzheimers Dis 2011;23:433-42 CrossRef Medline

10. Honea RA, Vidoni E, Harsha A, et al. Impact of APOE on the healthy aging brain: a voxel-based MRI and DTI study. J Alzheimers Dis 2009;18:553-64 Medline

11. Agosta F, Vossel KA, Miller BL, et al. Apolipoprotein E epsilon4 is associated with disease-specific effects on brain atrophy in Alzheimer's disease and frontotemporal dementia. Proc Natl Acad Sci U S A 2009;106:2018-22 Medline

12. Wishart HA, Saykin AJ, McAllister TW, et al. Regional brain atrophy in cognitively intact adults with a single APOE epsilon4 allele. Neurology 2006;67:1221-24 CrossRef Medline

13. Pennanen C, Testa C, Boccardi M, et al. The effect of apolipoprotein polymorphism on brain in mild cognitive impairment: a voxelbased morphometric study. Dement Geriatr Cogn Disord 2006;22: 60-66 CrossRef Medline

14. Liu Y, Paajanen T, Westman E, et al. Effect of APOE $\varepsilon 4$ allele on cortical thicknesses and volumes: the AddNeuroMed study. J Alzheimers Dis 2010;21:947-66 CrossRef Medline

15. Lupton MK, Strike L, Hansell NK, et al. The effect of increased genetic risk for Alzheimer's disease on hippocampal and amygdala volume. Neurobiol Aging 2016;40:68-77 CrossRef Medline

16. Wang X, Wang J, He Y, et al. Apolipoprotein E $\boldsymbol{\varepsilon} 4$ modulates cognitive profiles, hippocampal volume, and resting-state functional connectivity in Alzheimer's disease. J Alzheimers Dis 2015;45:781-95 CrossRef Medline

17. Susanto TA, Pua EP, Zhou J, et al. Cognition, brain atrophy, and cerebrospinal fluid biomarkers changes from preclinical to dementia stage of Alzheimer's disease and the influence of apolipoprotein e. J Alzheimers Dis 2015;45:-253-68 CrossRef Medline

18. Chen J, Shu H, Wang Z, et al. The interaction of APOE genotype by age in amnestic mild cognitive impairment: a voxel-based morphometric study. J Alzheimers Dis 2015;43:657-68 CrossRef Medline

19. Chen Y, Chen K, Zhang J, et al. Disrupted functional and structural networks in cognitively normal elderly subjects with the APOE $\boldsymbol{\varepsilon} 4$ allele. Neuropsychopharmacology 2015;40:1181-91 CrossRef Medline

20. Habes M, Toledo JB, Resnick SM, et al. Relationship between APOE genotype and structural MRI measures throughout adulthood in the study of health in Pomerania population-based cohort. AJNR Am J Neuroradiol 2016;37:1636-42 CrossRef Medline

21. Matura S, Prvulovic D, Jurcoane A, et al. Differential effects of the ApoE4 genotype on brain structure and function. Neuroimage 2014; 89:81-91 CrossRef Medline

22. Shaw P, Lerch JP, Pruessner JC, et al. Cortical morphology in children and adolescents with different apolipoprotein $\mathrm{E}$ gene polymorphisms: an observational study. Lancet Neurol 2007;6:494500 CrossRef Medline

23. O'Dwyer L, Lamberton F, Matura S, et al. Reduced hippocampal volume in healthy young ApoE4 carriers: an MRI study. PLoS One 2012;7:e48895 CrossRef Medline

24. Hämäläinen A, Grau-Olivares $\mathrm{M}$, Tervo S, et al. Apolipoprotein E epsilon 4 allele is associated with increased atrophy in progressive mild cognitive impairment: a voxel-based morphometric study. Neurodegener Dis 2008;5:186-89 CrossRef Medline

25. Risacher SL, Shen L, West JD, et al; Alzheimer's Disease Neuroimaging Initiative (ADNI). Longitudinal MRI atrophy biomarkers: relationship to conversion in the ADNI cohort. Neurobiol Aging 2010; 31:1401-18 CrossRef Medline
26. Folstein MF, Folstein SE, McHugh PR. "Mini-mental state": a practical method for grading the cognitive state of patients for the clinician. J Psychiatr Res 1975;12:189-98 CrossRef Medline

27. Zigmond AS, Snaith RP. The hospital anxiety and depression scale. Acta Psychiatr Scand 1983;67:361-70 CrossRef Medline

28. Barberger-Gateau P, Commenges D, Gagnon M, et al. Instrumental activities of daily living as a screening tool for cognitive impairment and dementia in elderly community dwellers. J Am Geriatr Soc 1992; 40:1129-34 CrossRef Medline

29. Wechsler DA. Wechsler Memory Scale. 3rd ed. San Antonio: Psychological Corporation; 1987

30. Reitan RM. Validity of the Trail Making Test as an indicator of organic brain damage. Percept Mot Skills 1958;8:271-76

31. Wechsler D. Manual for the Wechsler Adult Intelligence Scale. New York: Psychological Corporation; 1995

32. Milner B. Interhemispheric differences in the localization of psychological processes in man. Br Med Bull 1971;27:272-77 CrossRef Medline

33. Buschke H, Sliwinski MJ, Kuslansky G, et al. Diagnosis of early dementia by the Double Memory Test: encoding specificity improves diagnostic sensitivity and specificity. Neurology 1997;48:989-97 CrossRef Medline

34. Baddley A, Emslie H, Nimmo-Smith I. Doors and People. A Test of Visual and Verbal Recall and Recognition. Bury St. Edmunds: Thames Valley Test Company; 1994

35. Kaplan EF, Goodglass H, Weintraub S. The Boston Naming Test. 2nd ed. Philadelphia: Lea \& Febiger; 1983

36. Schnider A, Hanlon RE, Alexander DN, et al. Ideomotor apraxia: behavioral dimensions and neuroanatomical basis. Brain Lang 1997;58:125-36 CrossRef Medline

37. Poeck K. Clues to the nature of disruption to limb Praxis. In: Roy EA, ed. Neuropsychological Studies of Apraxia and related Disorders. Amsterdam: North-Holland; 1985:99-109

38. Welsh KA, Butters N, Mohs RC, et al. The Consortium to Establish a Registry for Alzheimer's Disease (CERAD), Part V: a normative study of the neuropsychological battery. Neurology 1994;44:609-14 CrossRef Medline

39. Hughes CP, Berg L, Danziger WL, et al. A new clinical scale for the staging of dementia. Br J Psychiatry 1982;140:566-72 CrossRef Medline

40. Petersen RC, Doody R, Kurz A, et al. Current concepts in mild cognitive impairment. Arch Neurol 2001;58:1985-92 CrossRef Medline

41. Xekardaki A, Rodriguez C, Montandon ML, et al. Arterial spin labeling may contribute to the prediction of cognitive deterioration in healthy elderly individuals. Radiology 2015;274:490-99 CrossRef Medline

42. Nauck M, Hoffmann MM, Wieland H, et al. Evaluation of the apo E genotyping kit on the LightCycler. Clin Chem 2000;46:722-24 Medline

43. Smith SM, Nichols TE. Threshold-free cluster enhancement: addressing problems of smoothing, threshold dependence and localisation in cluster inference. Neuroimage 2009;44:83-98 CrossRef Medline

44. Fouquet M, Besson FL, Gonneaud J, et al. Imaging brain effects of APOE4 in cognitively normal individuals across the lifespan. $\mathrm{Neu}$ ropsychol Rev 2014;24:290-99 CrossRef Medline

45. Teipel S, Grothe MJ; Alzheimer's Disease Neuroimaging Initiative. Does posterior cingulate hypometabolism result from disconnection or local pathology across preclinical and clinical stages of Alzheimer's disease. Eur J Nucl Med Mol Imaging 2016;43:526-36 CrossRef Medline

46. Chételat G, Ossenkoppele R, Villemagne VL, et al. Atrophy, hypometabolism and clinical trajectories in patients with amyloidnegative Alzheimer's disease. Brain 2016;139:2528-39 CrossRef Medline

47. Raji CA, Lopez OL, Kuller LH, et al. White matter lesions and brain 
gray matter volume in cognitively normal elders. Neurobiol Aging 2012;33:-834.e7-16 CrossRef

48. Perkins $\mathrm{M}$, Wolf $\mathrm{AB}$, Chavira $\mathrm{B}$, et al. Altered energy metabolism pathways in the posterior cingulate in young adult apolipoprotein E $\boldsymbol{\varepsilon} 4$ carriers. J Alzheimers Dis 2016;53:95-106 CrossRef Medline

49. Lu H, Fung AW, Chan SS, et al. Disturbance of attention network functions in Chinese healthy older adults: an intra-indi- vidual perspective. Int Psychogeriatr 2016;28:291-301 CrossRef Medline

50. Albert MS, DeKosky ST, Dickson D, et al. The diagnosis of mild cognitive impairment due to Alzheimer's disease: recommendations from the National Institute on Aging-Alzheimer's Association workgroups on diagnostic guidelines for Alzheimer's disease. Alzheimers Dement 2011;7:270-79 CrossRef Medline 